\title{
Feet of Lead; Ships of Lead
}

John Buglass ${ }^{1}$

How to cite: Buglass, J. Feet of Lead; Ships of Lead. Papers from the Institute of Archaeology, 2021, 30(1): pp. 26-48. DOI: https://doi.org/10.14324/111.444.2041$\underline{9015.1284}$

Published: 15/11/2021

\section{Peer Review:}

This article has been peer reviewed through the journal's standard double-blind review.

\section{Copyright:}

(c) 2021, The Author(s). This is an Open Access article distributed under the terms of the Creative Commons Attribution License (CC-BY) $4.0 \mathrm{https}: / /$ creativecommons.org/licenses/by/4.0/, which permits unrestricted use, distribution and reproduction in any medium, provided the original author and source are credited • DOI: https://doi.org/10.14324/111.444.2041-9015.1284

\section{Open Access:}

Papers from the Institute of Archaeology is a peer-reviewed open access journal. 


\title{
CONFERENCE PROCEEDINGS: TIMELESS SPACES 2019*
}

\section{Feet of Lead; Ships of Lead}

John Buglass

\begin{abstract}
A survey of the tower of St Oswald's Church, Filey, North Yorkshire recorded nearly 1500 graffiti spanning over 400 years. Visitors to the roof not only left their 'mark' but a range of iconography which throws light on such topics as literacy, fashion, a possible plague outbreak, occupations and personal relationships. The study of this graffiti produced a wealth of information on not only the people of Filey but on the early tourism to the town. The commonest images were the outlines of shoes, hands and sailing ships. A seemingly odd combination of imagery but one that, when looked at in detail, throws significant light on to the life and times in the 18th and 19th centuries in a Yorkshire coastal town. This paper will examine in more detail some of the information that can be obtained from a large collection of post-medieval graffiti of shoe and ship outlines that can be related to a specific time and place. Although the tower of St Oswald's contained examples of a wide range of graffiti including hands, fish, peel notations, love hearts and even a possible 'plague doctor' the focus of this paper is primarily on the shoe outlines and ship images as there would simply not be space to discuss all the examples in detail.
\end{abstract}

Keywords: Filey; shoes; ships; post-medieval; church

\section{Introduction}

Graffiti has probably been around for as long as humankind and it is arguable that some prehistoric cave art is simply very old graffiti. This can potentially be recognised in the parallels between the famous prehistoric hand stencils seen as far afield as Australia, Spain and France and the numerous outlines of hands (and feet) seen cut into the lead of many UK church roofs (e.g., Richardson \& Dennison 2014).

"Timeless Spaces: Between Art, Politics, and Vandalism, a Seminar on Ancient and Modern Graffiti was a conference held at the Institute of Archaeology, University College London on the $16^{\text {th }}$ of March 2019, organised by Rosamund Fitzmaurice, Tia Watkins and loannis Nakas. This paper is part of the proceedings of that conference and have been edited by the organisers, with the support of Papers from the Institute of Archaeology. 
Graffiti has not always been seen as the source of information and potential art form that it is nowadays. For example, in the 18th century Alexander Cruden (known as 'Alexander the Corrector' 1699-1770) saw it as his personal mission to safeguard the nation's spelling and grammar. He was particularly concerned with misspelt signs, graffiti and swearing and was in the habit of carrying a damp sponge to remove offending graffiti (Room 1999: 21).

Graffiti in its various forms can be often be a common sight in many urban areas and with the widespread use of spray paint it can be seen as a depressingly frequent form of damage to the fabric of historic buildings. Examples of graffiti can range from contentious modern 'tagging' through the political statements of Banksy and the Northern Ireland Troubles to historic examples of initials, dates and imagery. Due to human ingenuity, graffiti has been created in a multitude of ways on almost any surface you can think of. Some of the more exotic examples include blood, tar and chewing gum (Douglas 2014). These, and other examples do beg the question 'What is Graffiti?'. As this topic is one which has been given greater consideration elsewhere (e.g. Forster, Vettese-Forster \& Borland 2012) and is also discussed at length in this volume, this complex issue I have not discussed here.

The reasons for individuals creating graffiti are many and varied, but the most common seems to simply be the desire of the person to record their presence at that particular location at that moment in time - I'm Here. Other reasons for creating graffiti include political commentary/cartoons, insults, artistic endeavour, votive offerings and declarations of love (Buglass 2015: 6). In addition, a significant number of graffiti can be found to include some form of iconography such as people, animals, ships, vehicles, buildings and even clothing (Richardson \& Dennison 2014: 10). It was a complex combination of graffiti of names, dates and iconography cut into the lead of the tower of St Oswald's Church that formed the basis of a detailed study in 2015 and also forms the basis of this paper along with other examples drawn, primarily, from sites across the north-east of England.

St Oswald's Church is located on the northern side of Church Ravine in Filey, North Yorkshire (NGR TA 11778 81065). The church is a Grade 1 Listed Building with significant portions that date from the 12 th and 13 th centuries with $15^{\text {th }}$-century battlements. The church was restored and partly rebuilt in 1885 (Historic England 
2020). The graffiti studied for this paper is located on the lead roof of the tower which is towards the eastern end of the church and located over the crossing.

\section{What can we learn from graffiti?}

Possibly the first 'academic' treatment of graffiti comes in 1837 with the publication of Inscriptiones Pompeianae by Bishop Christopher Wordsworth (1807-1885) which provided detail into the everyday life of the '...scribblings and drawings of schoolboys and idlers at Pompeii.' (Macdonald 1977: 565). Although Wordsworth often seems more concerned with classical poetry he does comment on the possible lives and actions of those who created the graffiti and it is this investigation of the reasons why people create graffiti that can tell us much about the past.

Graffiti can be seen to represent the mark of the ordinary person and most frequently this 'common touch' reflects the desire of the person to simply record their presence at that location at that moment in time. However, people will also often record in the graffiti what is important to them. This can be seen in examples of graffiti from St Oswald's and elsewhere where studies have provided insight into: environmental change (Buglass \& Brigham 2010: 47), emancipation (Richardson 2013: 59-60), military history (Buglass 2016: 23), literacy (Richardson 2013: 21), building history (Richardson 2013: 59), fashion (Buglass 2015: 7-8; Richardson 2013: 60), travel and tourism (Buglass 2015: 5), contemporary technology (Richardson 2013: 65), people and occupations (Buglass 2016: 17) and changes in shipping (Buglass 2016: 41; Buglass 2013: 63). With this diverse potential there is only sufficient space here to consider two of the topics in detail - shoes and ships.

\section{Feet of Lead}

The commonest graffiti found on church roofs is the outline of shoes (Buglass 2016; Connisbrough Research and Archaeology Group (CRAG) 2019; Richardson \& Dennison 2014). From the size of the shoes, it would appear that the majority of the outlines have been created by tracing around the shoe placed on the sloping roof and thus are slightly over life-sized. If this is the case then the examples recorded at $\mathrm{St}$ Oswald's would almost all appear to be for adult males based on size and shape. There were, however, two small shoes which from their size would appear to represent child-sized shoes. 
At St Oswald's there were a total of 432 shoe outlines and of these, rounded toe shoes were the commonest $(n=323)$, followed by square toes $(n=77)$ (see Figure 1 for examples) and then pointed toes $(n=32)$. Out of all of these images 34 of them had legible dates spanning 350 years from 1624 to 1974, although the majority date to the 18th century, particularly the 1770s (see Table 1 for dates represented in the graffiti).

Table 1: Shoe outline shapes and associated dates.

Dated shoe toe shapes

\begin{tabular}{l|l|l}
\hline Rounded & Square & Pointed \\
\hline 17??, 1718, 1720, 1732, 1735, & $1624,1668,1696,1697$, & $1701,17 ? 7,1778$ \\
1739, 1747, 1749, 1759, 1763, & $1712,1718,1878$ & \\
$\begin{array}{l}\text { 177?, 1770, 1772, 1773, 1777, } \\
\text { 1782, 1869, 189?, 1974 }\end{array}$ & & \\
\hline
\end{tabular}

It would be anticipated that the dates would relate to the changes in fashion and style of shoes and an examination of the dates showed that there is an overlap in dates between the types. However, the only possible trend was in square toed shoes which seem to date to the later 17 th century, with four of the six dated examples falling between 1624 and 1697.
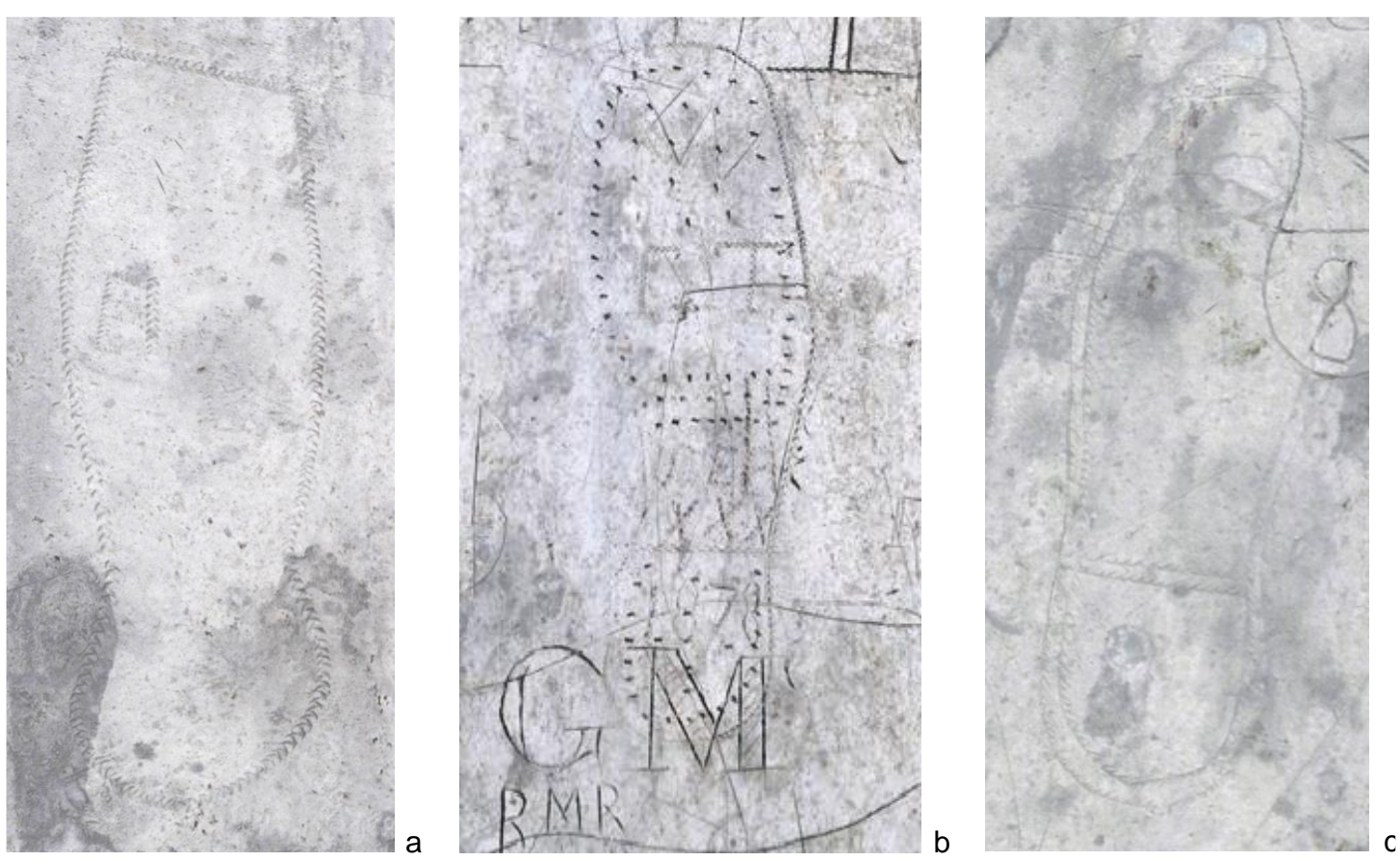

Figure 1: Examples of shoe graffiti. a) A very pronounced square toed shoe. b) Possible hobnails. c) Detail of the heel. 
Many of the shoe outlines contained initials/names and dates but in addition, a number of each of the forms had additional embellishment. These embellishments appear to represent constructional details of the shoe. For example, the possible hobnails on some of the round toe shoes (Figure 1b). Many of the shoe depictions are realistic in that they appear to show patterns of stitching around the welt. In some they clearly show the join between the heel block and the sole (Figure 2).

As well as the conventionally shaped shoe outlines, there were a number of outlines where either the mid-section of the shoe or the heel block appears to be shown in an exaggerated form. It is uncertain if this is a literal representation of a fashion style or artistic licence.
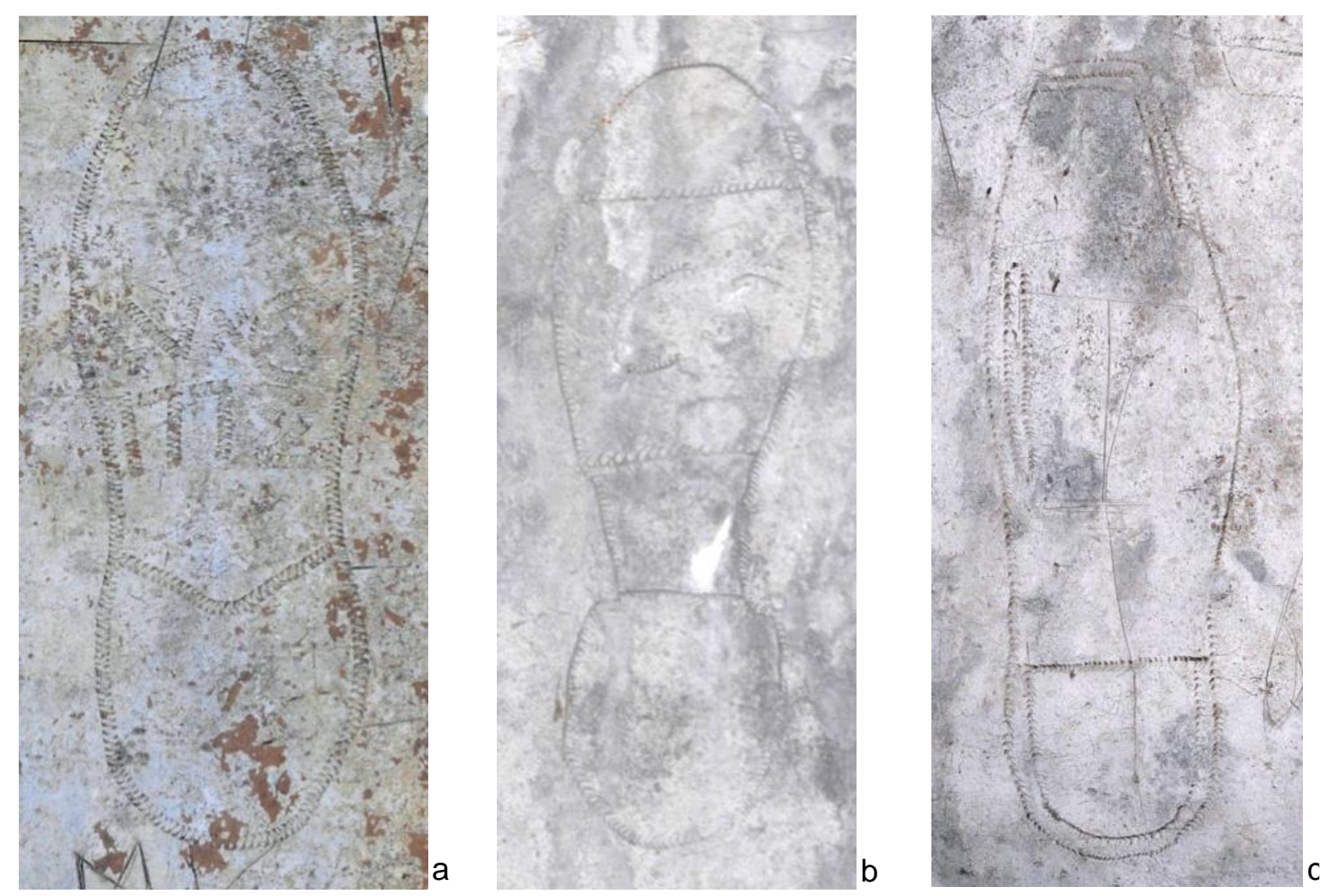

Figure 2: Examples of shoe graffiti. a)Details of stitching. b)Possible repair to the mid-section of the sole or to show a toe cap. c) Possible repairs.

There is an exception where there are two small, pointed shoes depicted (Figure 3), one dating 1709 with the initials IR and the other simply has the initials TI. From their size and shape, and if they are life sized, they would appear to represent child sized shoes and may be representative/commemorative of a child's birth or christening (Figure 3). In addition to the more realistic portrayal of the soles of some of the shoes, there were a few examples where there is a complex geometric pattern 
within the sole (Figure 4). These designs appear to have no more significance than being a purely decorative device around the person's initials.

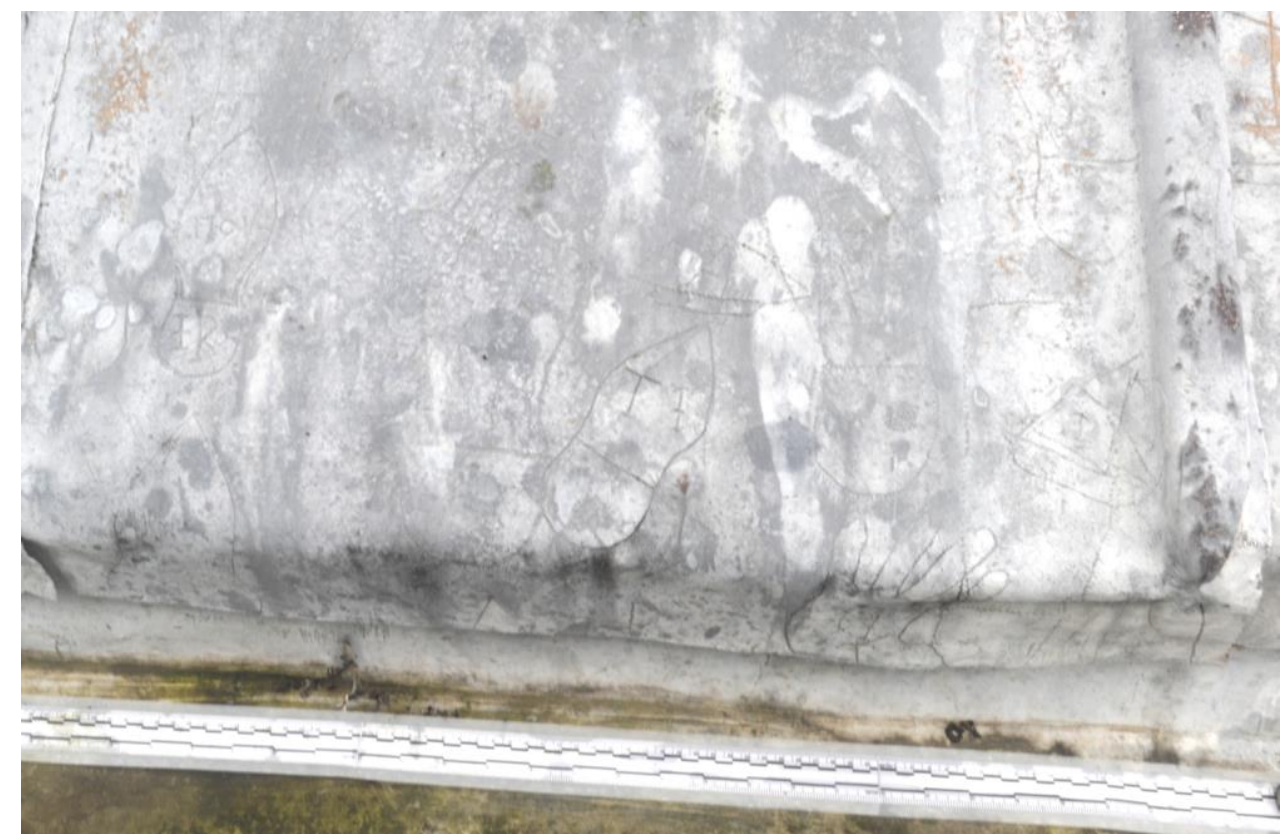

Figure 3: Two small/child's shoe outlines.

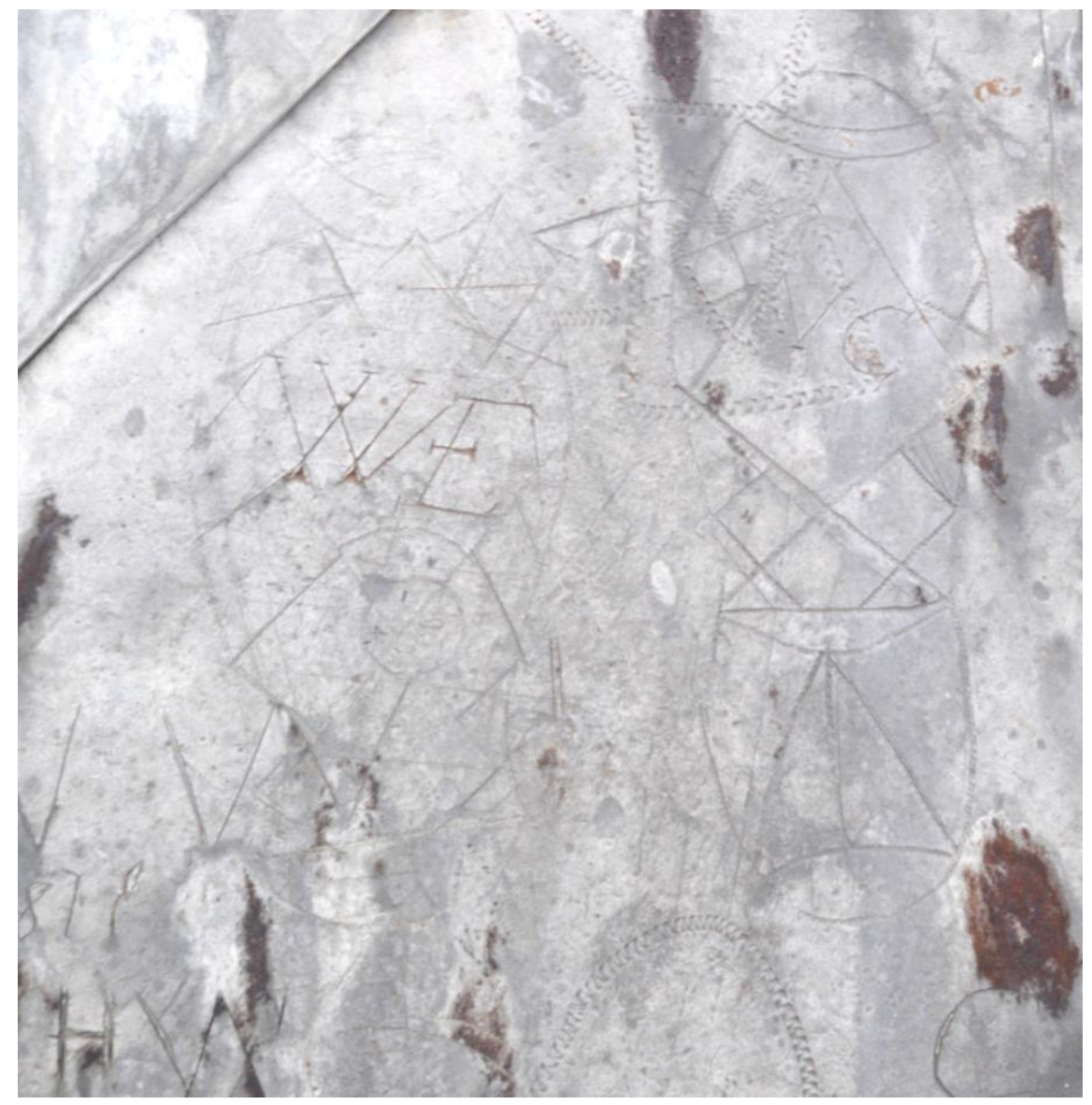

Figure 4: Geometric patterns in two shoe outlines. 
In addition to the many shoe outlines, there were two depictions of shoes in profile. One of the images is much simpler than the other and consists of a basic outline of a block heeled, square toed shoe with what appears to be an undone buckle as the fastening (Figure 5). The sketch of the graffiti provides a detailed representation of the complex linework of the shoe. The image is actually composed of two outlines and appears to have originally been cut as a 'wrigglework' design. Then at a later date someone has gone over it with a simple scored line, possibly with the aim of enhancing the original image. Careful examination of the image shows that the original wrigglework design is much more detailed than the later scored line. The wrigglework outline shows a high tongued shoe with what could be a bow or other decoration on the front. The later scored outline is a simpler rendition of the original image and appears to add a possible buckle or strap across the front.

Wrigglework is a technique where a suitably shaped tool was pushed over the surface at a $45^{\circ}$ angle, whilst being rocked (wriggled) from side to side. In engraving a specialist tool known as a "flat scorper" or graver tool was used (Maryon 1971: 153). A similar effect could also be achieved with an item such as a small woodworking chisel or a $\mathrm{V}$ racer used in leatherworking. This technique was commonly used in engraving in the late 17th and early 18th centuries (Victoria and Albert Museum 2016) and as such helps to form a chronology for the creation of the graffiti. It is interesting to note how much of the graffiti has been created in wrigglework which indicates that those people creating the wrigglework graffiti are going to the roof suitably equipped with a specialist tool in order to do so. This in turn suggests a high degree of preparedness and preplanning rather than the graffiti being created as a spur of the moment impulse. The idea of preplanning can be seen to be supported in several examples where clear 'setting out lines' have been lightly scored into the lead, prior to the more elaborate wrigglework being formed over it. Both of the images would appear to be of $18^{\text {th }}$-century, square toe shoes with wooden block heels and probably buckle fastened. From their size it is assumed that they represent a male shoe.

Interestingly, one of the names on the roof (John Colling 1859) could be of a local shoemaker according to the births, marriages and deaths records as there was a John Colling born in Filey c.1820 and is listed in the census as a shoemaker in Moseys Yard in 1841. It is impossible to say however if he was responsible for either of the images, 
particularly as the images are not on the same panel as his name, though it must always be borne in mind that the sheets may have been re-laid/ordered and the name and images may once have been closer together.

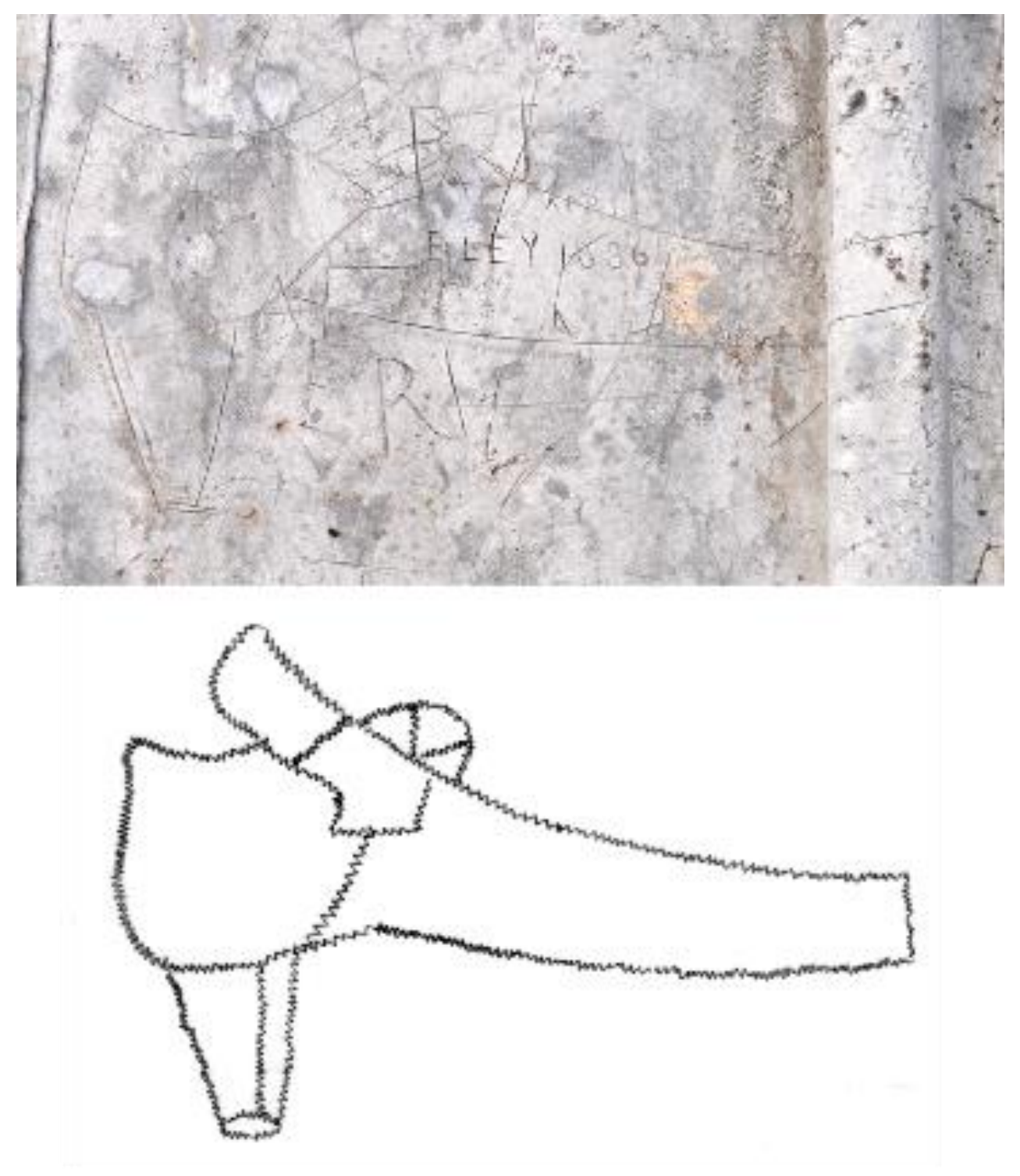

Figure 5: Profile of a shoe with sketch of detailed wrigglework.

Although the majority of the shoe graffiti are well formed, it is surprisingly difficult to determine if they are of the left or right foot. This is probably a result of a combination of difficulty in tracing around the shoe whilst leaning on the roof. In addition, historically there was relatively little differentiation between left and right shoes.

In the majority of the shoe outlines recorded, the toe was pointing towards the apex of the roof. This shows that the person would have been standing facing the roof 
and simply placed their foot on the roof and lent forward to trace the outline. There are however a number of exceptions to this. In a small number of shoe images the toe is either pointing down or across the slope of the roof. There are further examples where the outline is on the lead sheet which has been formed around either the edge of the roof or over the roll joints. In the case of all of the exceptions to the normal 'toe up' orientation, it would seem that the lead sheet they are on has been re-used in a different orientation/location from that in which it was in when the graffiti was originally created. Therefore, it should be possible by examining the location and dates of these graffiti to establish when some of the repairs/reordering to the roof may have taken place. Unfortunately, none of the examples of the non 'toe up' examples on the tower roof were dated. Similarly, there are a small number of locations where graffiti has been partially covered by a later re-laying of a lead sheet; again, none of these were dated.

\section{Ships of Lead}

As a necessity of sea level changes since the last ice age the UK has been a seafaring nation for the last 10,000 years. Because of this, ships and their development have been inextricably tied to the development of the country and until the advent of the air travel the country was entirely dependent upon ships for all foreign trade, diplomacy, movement of soldiers and the flow of scientific knowledge and art. This means that ships and maritime themes became embedded in everyday life from products (Ship matches; Cutty Sark scotch; Lifebuoy soap) to popular culture (HMS Pinafore; Jamaica Inn; The Tempest (based on the wreck of the Sea Venture)) and high art (The Fighting Temeraire). These examples can be seen as an 'official' expression of this deep-rooted acknowledgement of our maritime heritage - but what about the 'unofficial' expression of this in the form of graffiti?

A total of 47 ship images were recorded along with two further possible partial images of what appear to be the topmost portions of sails on a mast. Of these 47 images, ships with zero masts were the least represented $(n=3)$, ships with three masts were the second to least represented $(n=7)$, ships with 1 mast were the second most represented $(n=10)$, and the majority of ship depictions were two masted vessels $(n=27$; see Table 2 for details). However, the quality of these graffiti means that these apparent images could actually be a happenstance of random lines appearing to look 
like a simple ship's hull. All bar one of the images are shown in profile with the bows of majority of the ships pointing to the left. There is a single example of the bows pointing down the slope of the roof, which would appear to be as a result of the relaying of the lead sheet. The one ship that is not shown in profile is a single masted vessel that has been shown in perspective as if the vessel was approaching the observer, who is looking towards the forrard starboard quarter (the forrard or forward is the fore part of ship, so forrard starboard quarter becomes front right portion of the bows of a ship when looking from the stern (rear) straight ahead; Figure 6). This three-dimensional representation of a ship is very unusual and no other examples are known of by the author. This perspective image at St Oswald's shows considerable flair for artistic representation and has been created using the minimum number of lines to give a strong impression of a sailing vessel underway and would appear to represent a Yorkshire fishing coble.

Table 2: Description and breakdown of ship graffiti.

\begin{tabular}{c|ccc} 
No. of Masts & Sail Plan? & Bow Facing & Freq \\
\hline $\boldsymbol{0}$ & No & Left & 1 \\
$\boldsymbol{0}$ & No & Right & 2 \\
& & & \\
1 & Yes & Left & 7 \\
$\mathbf{1}$ & Yes & Right & 3 \\
& & & \\
2 & Yes & Left & 17 \\
2 & Yes & Right & 6 \\
2 & No & Left & 3 \\
2 & No & Down & 1 \\
& & & \\
3 & Yes & Left & 3 \\
3 & Yes & Right & 3 \\
& No & Left & 1 \\
\hline
\end{tabular}

What is striking about many of the images is that they have been created with a considerable amount of detail relating to the shape of the hull, the manner of sail construction, standing and running rigging as well as constructional details of strakes (a set of planks running longitudinally from bow to stern in a wooden vessel), rudders, the shape of the stem (the foremost piece of wood uniting the bows) and stern and, in one case possible gun ports. This shows that at least some of the graffiti must have been created by someone with a good working knowledge of ships - either 
from first-hand experience on board or from long term observation of vessels. This level of detail can often allow for a reasonably accurate interpretation to be made of the type of vessel depicted which, in some cases, can provide a broad date to be placed upon the graffiti.

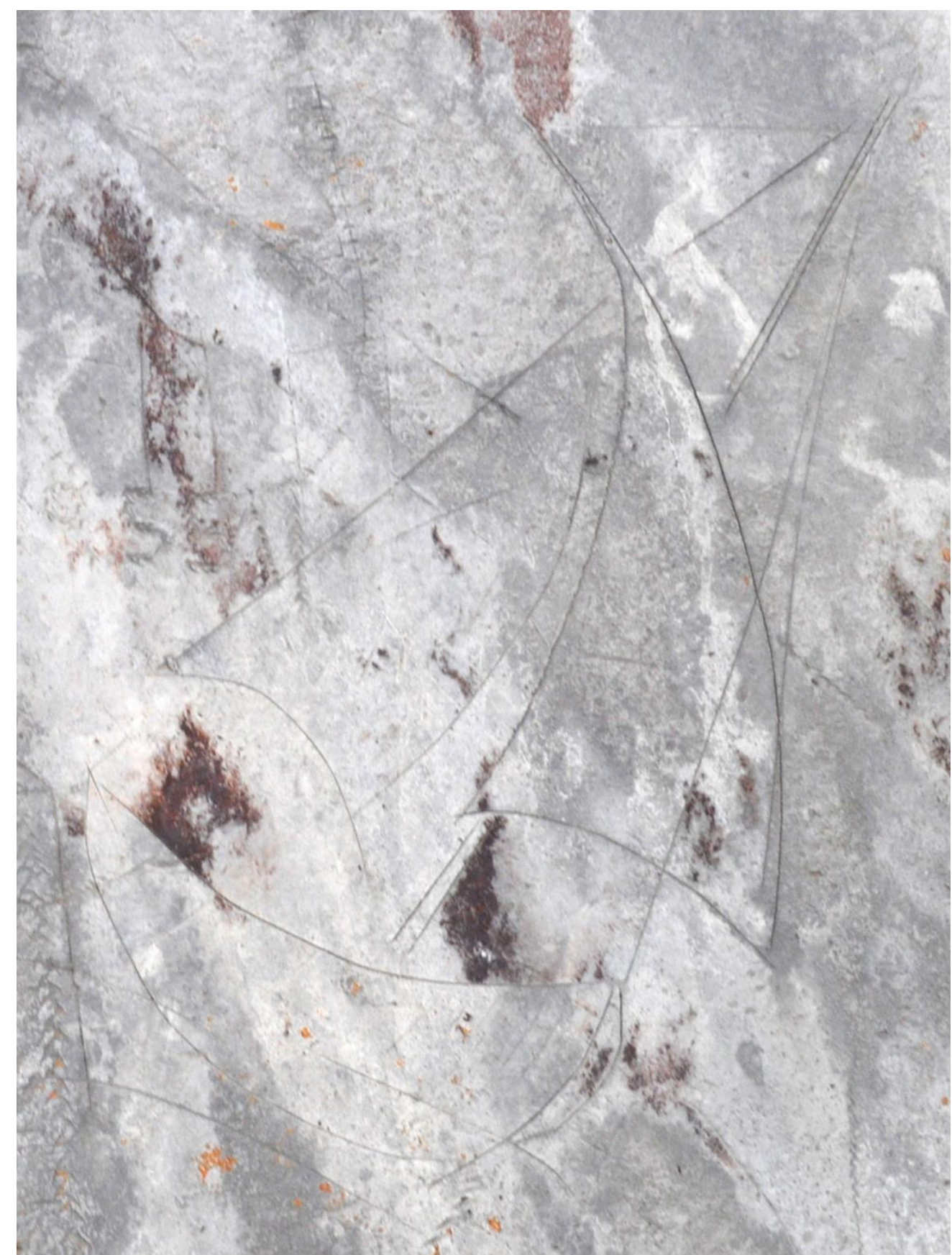

Figure 6: Yorkshire cobble (type of north-east fishing vessel particularly associated with North Yorkshire) under sail. 
When attempting to interpret the images of ships, it should always be borne in mind the limitations of the graffiti, both in the ability of the creator and medium upon which it has been created. The nature of the graffiti will limit the ability of the creator to reproduce as many details as accurately as they would like and a degree of latitude needs to be used when trying to determine what was being portrayed. The majority of ship types are determined by the arrangement of the sails over a number of masts. The classification of a ship can be changed by simply re-arranging the sails in a different configuration - known as a sail plan. This can often mean that the definitions of what constitutes, for example, a brig rigged ship may not always be reflected in real life. In the interpretations below an attempt has been made to 'best fit' the ship graffiti into recognised types, based mainly on the various sail plans and as such there will always be a degree of ambiguity in the resulting interpretations.

\section{Single masted vessels}

The graffiti of single masted vessels show four different types of sailing ships. The commonest representation is of a topsail cutter with three of the images having detailed sail plans. The best example (Figure 7a) not only shows the sail plan but also clearly depicts the reefing lines (short lengths of rope set in the sails used to partially roll up or furl a sail to reduce the area of the sail in strong winds) hanging down on the lower edge of the main sail along with the rudder. A further image also shows a vessel with a rudder, whilst another shows a well-defined, typical cutter stern.

The second type of single masted vessel shown is markedly different from all the other ship images. The two strikingly similar images can be seen on two adjacent sheets (Figure 7b) and if one was looking to compare it with regional ship types then a close match would be a Humber sloop. However, the Humber sloop is usually considered to be a vessel of large rivers or estuaries and it would seem unlikely that one would have ventured as far from the Humber Estuary as Filey Bay - assuming the image has been created as a result of seeing such a vessel locally. A much closer match in vessel type, with the distinctive forrard set mast, is a wherry or much more likely a sailing barge. As with the Humber sloop, the wherry is a riverine vessel and would not normally be seen on the open sea. 

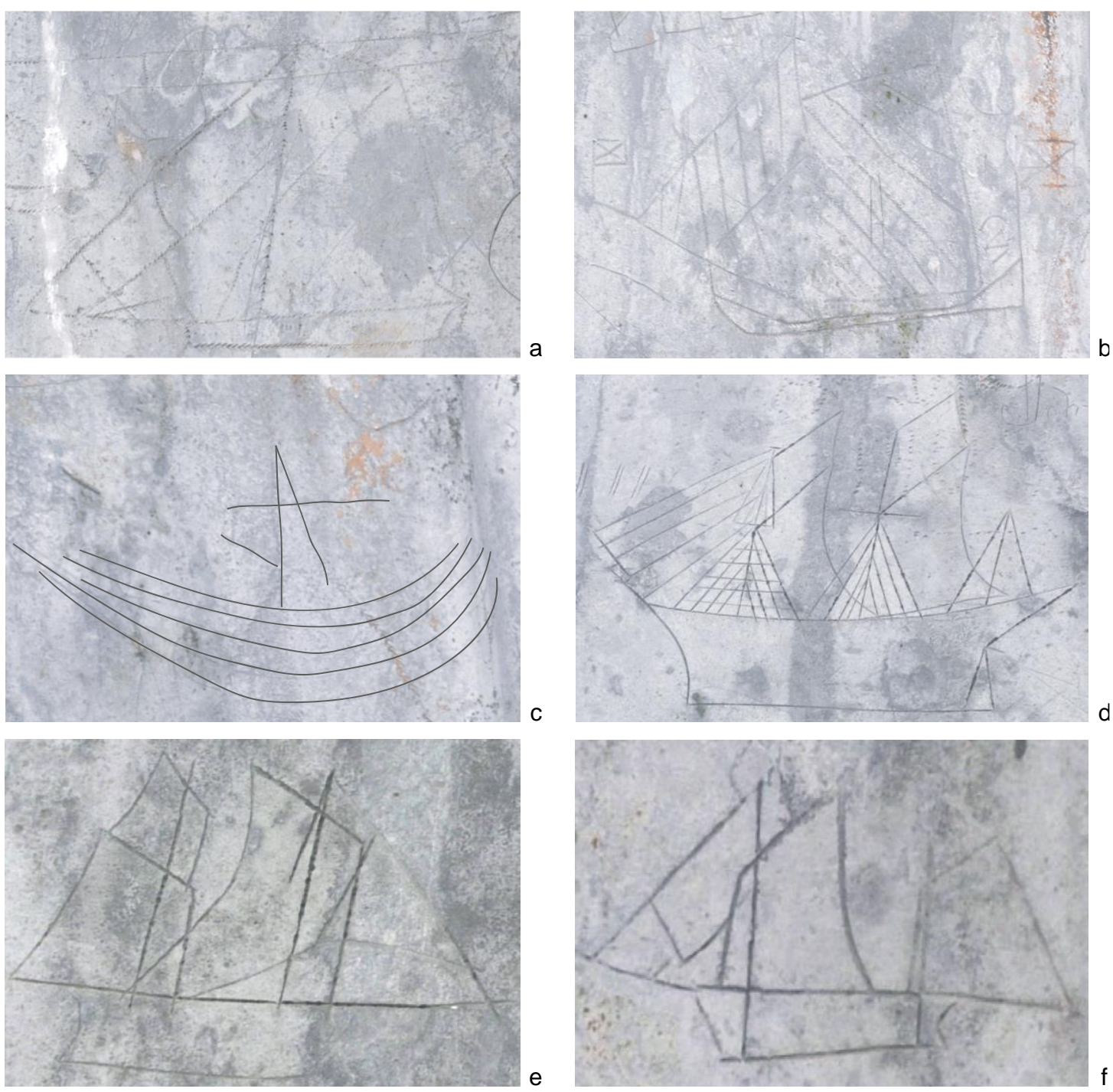

Figure 7: Examples of one and two-masted vessels. a) Topsail cutter. b) Possible sailing barge. c) Possible representation of a medieval hull. d) Possible topsail rig. e) Sailing brig with linework sketch superimposed for clarity. f) Fishing yawl.

Both of the graffiti show a vessel with a very low freeboard (suggesting heavily laden), a mast set well forrard with a large square-rigged sail. All of these characteristics are typical of sailing barges, although an aft mizzen mast, (the rear-most mast on a sailing vessel) and a common feature on sailing barges, seems to be lacking. However, what appears to be shown as a flagstaff at the rear of the vessel could well be a poorly represented mizzen mast. The occurrence of a sailing barge on the north-east coast would seem to be unusual as sailing barges are more commonly associated with the south coast and Thames Estuary area. A possible reason for its presence has been noted in the Rapid Coastal Zone Assessment of Yorkshire and Lincolnshire (Brigham 2014: 61). The survey records a small dock cut into the foreshore platform below Speeton Cliff at the southern end of Filey Bay. The dock was called Dulcey 
Dock and was apparently named after the coaster Dulcey, which used the site to collect mineral rich nodules from the beach and cliffs. It is possible that the vessel shown in the graffiti on the roof is a representation of the coaster working out of Dulcey Dock. If this is the case then it would seem to potentially date this image to the first half of the 19th century, as it is known that the nodules were being collect from c.1830s onwards and Dulcey Dock is present before the OS first edition of 1854 (Brigham 2014: 61)

Both of these graffiti show details of the sail construction with a series of parallel lines representing the individual strips of sail cloth that would have been sewn together to produce the required size of sail. This detail shows a degree of familiarity with sailing ships.

One of the images of a single masted vessel has a rig reminiscent of a topsail cutter, but also appears to carry a spinnaker sail. This would seem to be unlikely however as this type of sail is a more recent development in sailing and the image is probably a more generic version of a sailing cutter.

The final image of a single masted vessel is a very faint image which is partially in the roll joint between two sheets of lead (Figure 7c). The image appears to show a hull formed from four strakes with a very upturned bow and stern giving it a distinctive appearance. The narrowing of the image to the left would seem to show the bows, whilst approximately amidships there is a single mast with a crossed yard (or sail yard, the name for the spars or horizontal timbers from which the sails hang). The crescent shaped hull, single mast and yard are all considered to be very characteristic of a type of vessel knows as a hulk common in the $13^{\text {th }}-14^{\text {th }}$-century (Friel 1995, 21; Hutchinson 1994: 10). This type of vessel is usually dated to the 13/14th centuries and, if this was the case, then this section of the roof, at least, is considerably older than had previously been assumed. However, as the image is faint and quite simplistic it is possible that it is either a more recent and naive representation of a ship (or even not of a ship at all).

\section{Two masted vessels}

Representations of two masted vessels were by far the commonest images of ships and showed a wide variety of detail in relation to the sail plans, rigging and hull forms. 
One of the images was overlain by a re-laid lead sheet, which meant that it was too obscured to be able to suggest a possible vessel type. Three of the images were of a simple hull with bare, stick like masts.

One very noticeable feature on several of the two masted vessels was that the masts were set well forrard and aft (Figure 7d). The arrangement appears to be a deliberate portrayal and not simply artistic licence. This spacing of the masts shows that there has been a large area of deck space left clear for either working in (e.g. for working nets or processing fish) or to accommodate a feature such as a moon pool. The moon pool was either an opening in the bottom of the hull giving access to the water below or a large, sea water filled tank used to keep the catch live until return to port. In the latter case the base of the tank was often perforated to allow the sea to flow freely in and out of the tank to keep the catch live (Buglass 1997: 50). A further possibility is that the central area was used to carry smaller fishing vessels which could be offloaded once the main fishing grounds had been reached for example the Dogger Bank and Silver Pit (two very productive fishing grounds) in the southern North Sea in the 19th and early 20th century.

Four of the graffiti show what can be considered to be variations on the basic plan of a brig (Figure 7e). As with the other images they show varying degrees of detail of standing rigging, and hull form.

Five of the vessels appear to have a straightforward square sailing rig, although some of these could just be a simple 'generic' rendition of a person's idea of what a sailing ship should look like. The most evocative image of a square-rigged ship can be seen in Figure 8a. Here the multiple horizontal lines give a good impression of the towering mass of sails expected on this type of ship.

The commonest type of two masted vessel depicted shows a simple sail plan of two triangular sails, one on each mast (Figures $8 \mathrm{~b}$ and $8 \mathrm{c}$ ). Some of the vessels also appear to also have a single foresail making it more akin to a lugger rig. This type of rig, with variations, is very similar to that of a 'Scarborough' yawl or Hull duster, both common types of vernacular fishing vessels operating out of Hull (see Figure 7f, Mannering 1997: 54). Both of these would have been common fishing vessels operating in the area. 

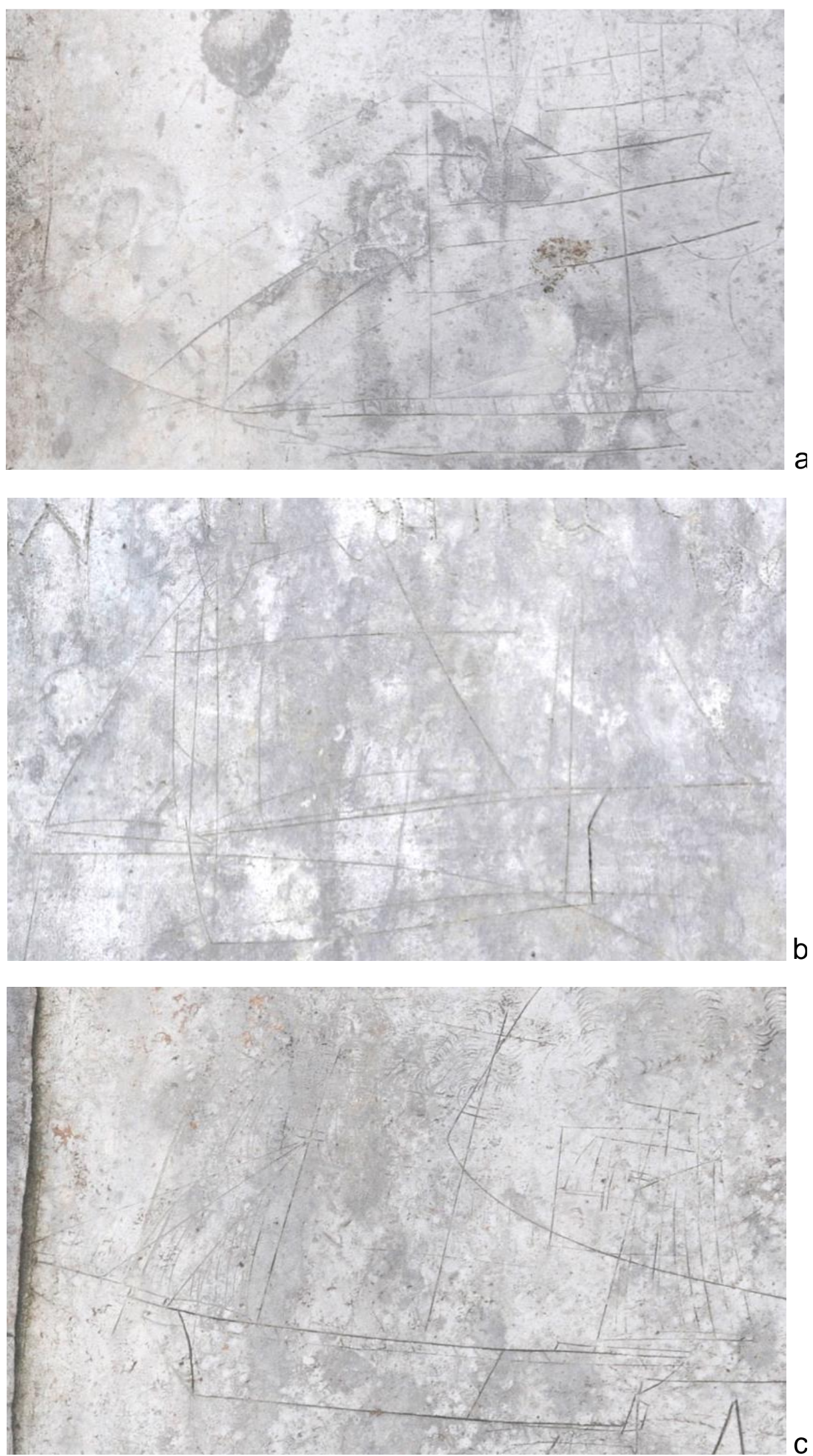

Figure 8: a) Square-rigged sailing vessel. b) A two-masted vessel with central working area. c) A two-masted vessel, with later addition of a third mast. 
Three masted vessels

Of the eight representations of three masted vessels, four appear to show three different types of sail plan. The remaining four images do not show any detail of a sail plan as the images were mainly of masts only. In the one example where there could have been sails, the lines in the image do not form a clear pattern. A second example is what appears to be a very limited sail plan (see Figure $7 \mathrm{~d}$ ). The graffiti has considerable detail on the standing rigging including shrouds, ratlines (ropes that run horizontally between the shrouds that forms steps to climb the rigging), crossed sail yards and stays (a strong rope running form the top of the mast to the stem to prevent excess movement in the mast, part of the standing rigging) as well as the typical stem and stern of a schooner. The image appears to show two topsails and may well have been rigged as a topsail schooner or ketch. A further graffiti shows a simple outline of a ship with what is probably a lugger type rig.

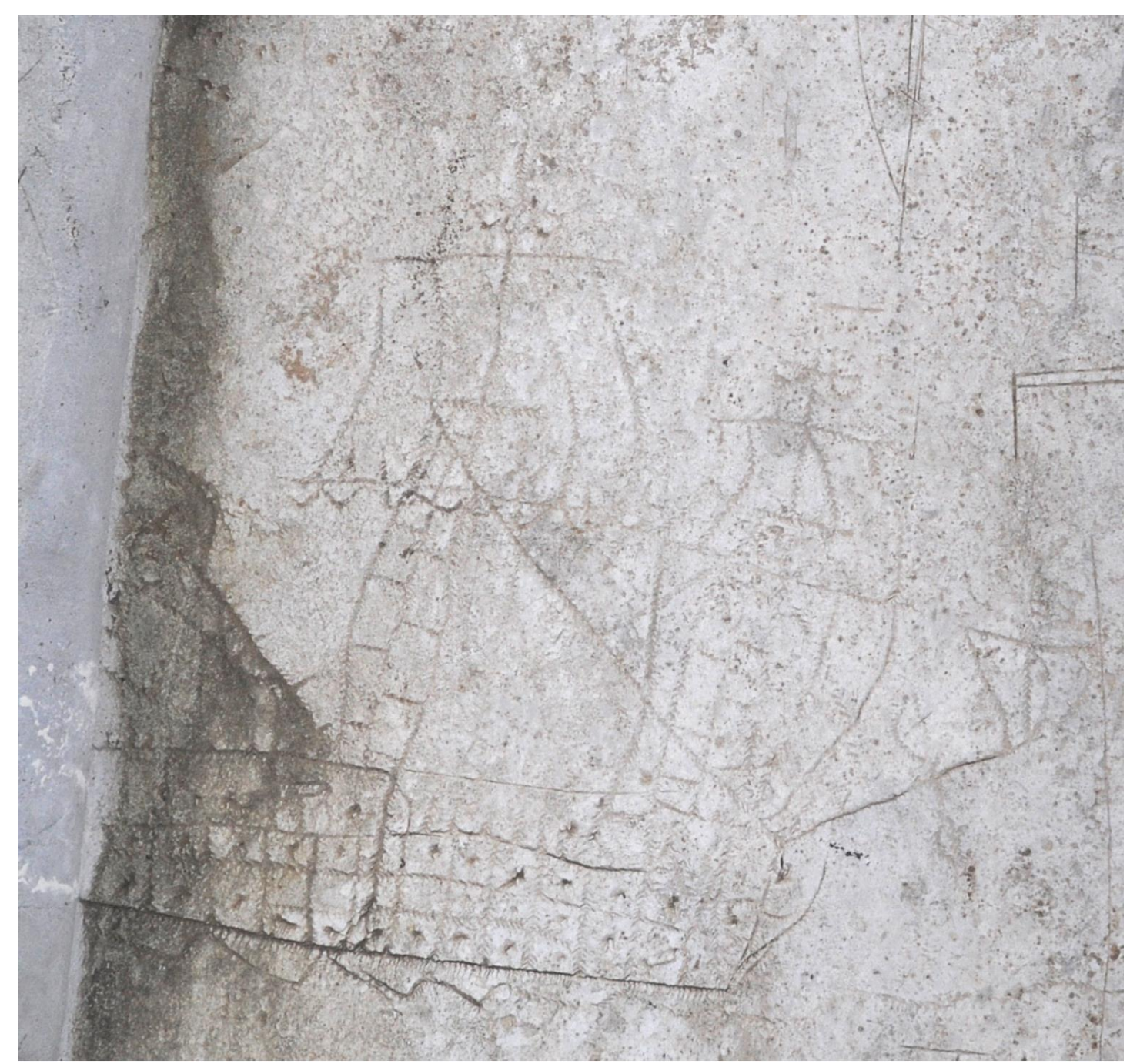

Figure 9: Possible armed sailing vessel 
Whilst the image in Figure 9 is one of the poorer representations of a ship, it is one of the more interesting ones. The graffiti shows a three masted vessel with what appears to a ship, or square, sailing rig. The image also includes details of some of the standing and running rigging (those elements of the rigging which are used to hoist and trim the sails). The running rigging can be seen in the partially furled sails hanging from three of the spars (two on the main mast and one on the foremast). Elements of the standing rigging can be seen in the shrouds that support the main and fore masts, along with the horizontal rat lines used to climb to the upper rigging. There are also what appear to be backstays running between the hull and the masts and from the foremast down to the bowsprit. The few sails that are shown have a minor amount of detail showing the seams on them.

Within the hull there is a suggestion of a raised quarter deck to the rear of the ship and under the bowsprit there is a possible beakhead (protruding part at the front of a ship to allow work on the bowsprit) depicted. Probably the most striking feature of this graffiti is the chequer-board pattern given to the hull with a central dot in many of them. It is possible that this is intended to represent guns in gun ports and that overall, the image is supposed to be a warship. The lowermost row of guns would seem to be perilously close to the water line however. The square rig, possible quarter deck and beakhead could place this image in the later 17 th to early 18th centuries. Interestingly this is one of only two images which show the surface of the sea either as a line or, as in the case here, as waves.

One of the most detailed representations of the hull of a vessel shows the hull in considerable detail whilst the masts and sail plan are sketchier. This may suggest that whoever created this image was more familiar with the construction of the hull than the operation of the sails, as seen by the foremast apparently piercing the sail. Alternatively, it could be possible that the graffiti was never finished and the details of the sails have simply not been added.

The constructional details of the hull that are shown include:

- the keel with stem and stern posts

- the garboard strake (the strake immediately adjacent to the keel) followed by nine sets of strakes (the lines of the hull planking) all of which rise toward the stem and stern 
- a rudder with what would be iron straps holding the sections together

- a bowsprit with a clamp to join the next section

- the main mast is set into the keelson (large longitudinal timber directly over the keel which clamps in place the lower end of the ships frames) whilst the fore and mizzen masts stopping at what would be the orlop deck

- possibly netting over the quarter/poop deck area

- a raised foredeck/forecastle (or fo'csal, a short deck in the front part of a ship, derived from forecastle in medieval warships) with a possible ladder at the front of it

- a crows nest on main mast

- backstays to support the masts but, interestingly, no shrouds

Overall, the graffiti shows a vessel with a very vertical stem (bow) and stern with the curves of the strakes showing a ship with a large cargo capacity. As such this may well be a representation of a 'Whitby cat' which was a very common type of merchantman that was usually brig rigged (March 2005). Overall, the various details in this graffiti would possibly date it to the later 18th or 19th century.

The last graffiti of a three masted vessel appears to have originally been created as a two masted ship with an extra section and mast added to the stern of the image (Figure 8c). Whether this was an addition by the original person or by another hand cannot be determined. However, as there is very little difference between the two parts of the image it would seem to suggest it was all created by the same person.

The sail plan of the vessel is that of a brigantine with details of the sail construction being clearly shown although there is no sign of the standing rigging. The hull details include a rounded stern, the rudder and possible crow's nests. As with the image described above, the bow and stern are generally quite vertical suggesting a merchantman. The image is probably of 19th-century date.

Within the collection of images there are several features of note in addition to the details of hull types and sail plans. One of these is that in most of the graffiti they show the hull down to the keel. If the ship was being observed whilst underway then one would expect either a water line to be shown partway up the hull or only part of the hull to be visible (Figure 9). However, if the ships were beached for 
loading/offload then it would be possible to see the whole of the hull and it is possible that many of these representations are of coastal traders off-loading on the sands in Filey Bay.

A further feature of note is that all the vessels depicted are sailing ships and there are no steamships represented, unlike at St Mary's Church in Whitby where, amongst the collection of ship graffiti cut into the pews, there are at least two representations of steamships (White 1994: 31, 34). The lack of images of steamers is probably due to the fact that Filey Bay would probably be too shallow for such ships to come inshore, coupled with no suitable harbour facilities to accommodate them.

Many images are generally very well executed and show a considerable, first-hand knowledge of sailing ships. This in turn suggests that the people creating them were well acquainted with ships either from working on or around them or seeing them on a daily basis.

\section{Where does graffiti end and art start?}

As already mentioned above the one ship that is not shown in profile is shown in perspective as if the vessel was approaching the observer, who would be looking towards the forrard starboard quarter (see Figure 6). This three-dimensional representation of a ship is very unusual. This simple depiction shows considerable flair for artistic representation and has been created using the minimum number of lines to give a strong impression of a sailing vessel underway and would appear to represent a Yorkshire fishing coble and as such this image can be seen to blur the line between art and graffiti, a topic discussed at length by Vettese-Forster and Forster (2012).

\section{Discussion}

The examples of graffiti described above are all recorded from the roof of the tower of a rural church situated on the north-east coast of England. This begs the question: is the graffiti in this location linked in some way to its location? In other words, does a church have graffiti which is unique to it being a church? Or is the graffiti more related to the coastal location - for example the numerous ship images? Or is it its rural location that could be an influencing factor, for example comparing this collection with the image of a plough cut into the plaster at Elling Farm, Berkshire (Kelly 2011)? 
Of the overall total of 1,482 graffiti recorded on the roof of the tower of St Oswald's very few could be specifically ascribed to being related to its role as a church. These examples included the name of the parish clerk (John Fox); tradesmen who were presumably there to carry out repairs (a plumber and stone mason) and the names of several bell ringers (including one graffito which included a peal notation). Beyond these few specific examples, the remaining graffiti appears to relate more to the building's location as a vantage point (for example the tourist graffiti from the late 19th century). Coupled with the opportunity to be away from public view and iconography of the graffiti it would suggest that the graffiti was produced because of the vantage point of the church roof in clear view of the sea. Furthermore, the isolated nature of roof surfaces generally have resulted in graffiti like hand and shoe outlines (CRAG 2019 and Richardson \& Denison 2014).

The one type of graffiti that does seem to be a direct result of the church's coastal location is the large number of ship images. This is probably a result of a combination of individuals creating images of what they can see from the roof top along with firsthand experience/knowledge of ships. This is particularly striking when the collection at St Oswald's is compared to that of All Saints at Wath upon Dearne (Richardson \& Denison 2014: 24). Here the All Saints survey did not encounter a single ship image but did record images of 13 birds and five riders and horses. This can potentially be seen to reflect its inland, more agricultural location. However, this potential link is by no means proven and would require a much larger set of comparisons to be made to produce and definitive link between location and iconography.

\section{Conclusion}

The various ship and shoe graffiti described above clearly illustrate a small part of the wide diversity and potential that post-medieval graffiti has. Study of this graffiti can show not only who was where at certain times but what was important to them on a day-to-day basis. Because this graffiti reflects the moment of time it was created it has an immediacy and intimacy that many contemporary written accounts lack. In addition, graffiti is typically produced by the general populace. Graffiti also has the advantage over written texts in that people who are illiterate can also create a record of what is important to them. The challenge for us in studying historic graffiti is to be able to unravel what it was that was so important to those who created the graffiti and how it may have been obscured by the passage of time. 


\section{REFERENCES}

Brigham, T 2014 Rapid Coastal Zone Assessment Yorkshire and Lincolnshire Project Overview. Thematic Discussion of Selected Aspects. English Heritage Project 3729. Phase 3. Humber Archaeology Report 422.

Buglass, J 1997 The Remains of Six Sailing Ships and Other Inter-tidal Archaeological Features Between Sutton on Sea and Mablethorpe, Lincolnshire. Unpublished Contractors Report.

Buglass, J \& Brigham, T 2010 Rapid Coastal Zone Assessment North Yorkshire, Whitby to Reighton. Phase 2. Humber Field Archaeology Report.

Buglass, J 2014 Comments of the Ship Graffiti. In: Robinson, T 2014, All At Sea in Ribblesdale. Yorkshire Buildings. The Journal of the Yorkshire Vernacular Buildings Study Group 41: 63-73.

Buglass, J 2015 The Moving Finger writes; and, having writ, Moves on: Historic Graffiti at St Oswald's Church, Filey, North Yorkshire. Archaeological Forum Journal, 4: 2-18.

Buglass, J 2016 Historic Graffiti on the Tower of St Oswald's Church, Filey, North Yorkshire. Recording and Interpretation. Unpublished contractors report.

Conisbrough Research and Archaeology Group 2019. St Peter's Church, Conisbrough, Church Tower Graffiti Survey. Unpublished Conisbrough Research and Archaeology Group report.

Douglas, M. 2014. Personal communication on blood used for graffiti in a Sheffield drug den.

Forster, A M, Vettese-Forster, S \& Borland, J 2012 Evaluating the cultural significance of historic graffiti. Structural Survey: Journal of Building Pathology \& Refurbishment 30(1): 43-64.

Friel, I 1995 The Good Ship. Ships, Shipbuilding and Technology in England 122-1520. London: British Museum Press.

Historic England 2020 Church of St Oswald. Available at: https://historicengland.org.uk/listing/the-list/list-entry/1316455. [Last accessed 10 September 2020.]

Hutchinson, G 1994 Medieval Ships and Ship Building. London: Leicester University Press. 
Kelly, N 2011 Personal communication on the graffiti at Elling Farm, Berkshire.

Macdonald, A M 1977 (ed) Chambers Twentieth Century Dictionary. Chambers Edinburgh.

Mannering, J 1997 Inshore Craft. Traditional Working Vessels of the British Isles. London: Chatham Publishing.

March, E J 2005 Inshore Craft of Great Britain in the days of sail and oar. London: Chatham Publishing.

Maryon, H 1971 Metalwork and Enamelling. Rev. 5th ed. New York: Dover Publications.

Pritchard, V 1967 English Medieval Graffiti. Cambridge: Cambridge University Press.

Richardson, S 2013 The Archaeological Recording of Graffiti in Yorkshire. Archaeological Forum Journal: CBA Yorkshire 2: 57-68.

Richardson, S \& Dennison E 2014 Church of All Saints, Wath Upon Dearne, Rotherham, South Yorkshire. Archaeological Recording of Graffiti. Unpublished Contractors Report 2013/452R.01.

Room, A 1999 Brewer's Dictionary of Phrase and Fable. Cassell. London

White, A 1994 Carvings of Ships in Whitby Parish Church. Privately Published Booklet.

Vettese-Forster, S \& Forster A M 2012 Evaluating the historic graffiti adopting definitions of art. Journal of European Popular Culture 2(2): 113-28.

Victoria and Albert Museum 2016 Metalwork Decoration Techniques. Available at: http://www.vam.ac.uk/content/articles/m/metalwork-decorationtechniques/. [Last accessed 10 September 2020].

Wordsworth, C 1837 Inscriptiones Pompeianae: or, specimens and facsimiles of ancient inscriptions discovered on the walls of buildings at Pompeii. London: John Murray. 